\title{
Et In Arcadia Ego
}

\author{
by JAMES M. TURNBULL, St. John's, Newfoundland
}

Once a person has known the joys of the berry-picker, he finds Arcadia wherever the wild fruit ig row s. Recently for me it was in the high rocky hills of Newfoundland, where the velvety blueberries nestled in foliage already reddened by autumn's chill. In spite of the brilliant September sunshine, the wind had a keen edge to it that will be forever associated with Terra Nova. It dared us to climb up from the sheltered depression where the berries grew, to the crest of the range. In only a few minutes we were looking out beyond the vivid blue of Conception Bay immediately below us to the limitless reaches of the restless old Atlantic itself.

Yet the majesty and rugged strength of this setting merely enhanced by contrast the gentler Arcadia of the prairie hills. In spring in Manitoba there was always the unforgettable beauty of blossoms choke-cherry, cranberry, pin-cherry - and in the autumn the Brandon Hills were a berry-picker's paradise. Then too, among all the memorable sights and sounds on the lonely highway north of 53 leading into The Pas, there was none to delight the traveller's heart like the stretch of . wild raspberry canes on either side of that built-up road. Such an abundance of ripe fruit brought to mind pioneer tales of berry-picking expeditions "to the mountain," when the uneasy nervousness of the horses at night would waken the campers to the presence of four-foot marauders. However alarming such prowlers might have been in the early days, they make a more colorful story than clouds of voracious mosquitoes. Nowhere have these latter utterly ruined the berrypicker's pleasure as they did last August when we found luscious blackberries near a marsh at Shediac Bay in New Brunswick.

Even a green pasture in Manitoba carries no memory of mosquitoes to mar the excitement of finding ripe wild strawberries there. These are supreme among wild fruits. The last time I picked them was in the Blue Mountains, a height of some 6,000 feet, and as we approached the top we found here and there by the trail, patches of wild strawberry plants, with an occasional ripe cluster to reward the searcher.

Yet people in Newfoundland speak of "bake-apples" as though they were nothing short of ambrosia ... They are small yellow berries from the marshes, not unlike the raspberry in structure. A close second in favour seems to be the partridge berry. Now that we have walked the airy heights where the blueberries ripen perhaps it will be vouchsafed to us some day to discover the Arcadia where the others grow.

\section{The Countryside}

(Near Garson, Man.)

In the distance are the green-clad hills,

With fertile valleys in between, The farmer's cottage near at hand,

And well-tilled fields showing green.

The pleasant air is full of sound As the birds fly about,

And the children of the farmer

Are happy as they play and shout.

To slowly walk along the paths

In the bush near at hand,

With the glorious sun shining down, Makes life feel so grand.

The squirrel chatters on the tree.

While the hawk soars overhead, And the little chipmunk scurries about

Seeking his daily bread.

The murmering stream flows gently Along its gravelly bed, And in the pools adjacent,

The little frogs poke up their heads.

Oh let me walk over the countryside,

'Til the days of life are o'er,

What greater joy could come to me,

Than studying Nature's lore.

by Fred C. Meeres, Winnipeg, Man. 